\title{
The Analysis of Flouting Maxim in "UP!" Movie
}

\author{
Devian Try Gustary*, Suciati Anggraini \\ STBA Technocrat Tangerang, Indonesia \\ *deviantry87@gmail.com, suciatianggraini12@gmail.com
}

DOI: $10.20884 / 1 . j 1 i .2021 .12 .2 .4118$

\begin{abstract}
Article History:
First Received:

$21 / 04 / 2021$

Final Revision:

$05 / 12 / 2021$

Available online:

$31 / 12 / 2021$

ABSTRACT

This study is aimed at investigating the flouting maxim spoken by characters in "UP!" movie. Flouting maxims and strategies of flouting maxim performed by the characters in the movie are investigated. Cutting's theory (2002) is used to analyze the types and strategies of flouting maxims. The researcher also employed qualitative research method to collect the data. The result showed two important findings. First, four types of flouting maxims was found in the movie which are flouting maxims of quantity, quality, relation and manner. Flouting maxims of quality was ranked first since the characters intentionally say something that is considered to be false. Second, ten strategies of flouting maxims was found in the movie. The strategies are categorized as providing limited information, giving excessive information, hyperbole, metaphor, irony, banter, sarcasm, being irrelevant, changing the topic and being obscure. The amount of the strategy that frequently used to flout maxims was giving excessive information. It happened because the characters always give the information more than required.
\end{abstract}

Keywords: pragmatics; flouting maxims; strategies

\section{INTRODUCTION}

In every conversation, the communication between speaker and hearer is not always successful. Sometime misunderstanding happens between them It happens because the speaker does not have cooperative effort and makes the hearer cannot assume the meaning of the conversation (Ulfah \& Afrilia, 2018). By having cooperated principle makes the communication between speaker and hearer work effectively. In fact, the speaker sometimes unintentionally does not follow the rules of cooperative principle when they are having conversation with the listener (Wahyuni et al., 2019). Moreover, Yule (1996) stated that the conversation will run smoothly if the people follow the conversation principles which is called maxim.

According to the language phenomenon, it is important to know the field of communication and the meaning of communication itself. Cooperative principle means "Make your conversational contribution such as required, at the stage at which it occurs, by the accepted purpose or direction 
of the talk exchange in which you are engaged" (Grice, 1989; Levinson, 1983). These four maxims of cooperative principle play their roles in communication process. It means that in communication, the speaker should give the appropriate, true, relevant, brief, and orderly information in order to achieve a smooth and effective conversation.

However, practically, the participants is hard to observe the maxims in their statements. They sometimes break the maxims in their conversation due to some reasons which is called flouting maxim as part of non-observance maxim (Grice, 1989). The flouting maxim means the speaker deliberately does not fulfill the maxims. In this case, the speakers believe that the hearers recognize the words and be able to infer the implied meaning (Cutting, 2002; Grundy, 2000). Those flouting maxim categorized into four types namely flouting maxim of quality, flouting maxim of quantity, flouting maxim of relation and flouting maxim of manner (Grice, 1989; Mey, 1993; Yule, 1996).

Flouting maxims of quality is taken place if the speaker says untruthful statement or something which is considered to be false (Thomas, 1995). When the speaker talks briefly and excessively in giving information, he/she flout the maxims of quantity. Then, flouting maxims of relation is happened if the speaker talks out of the topic of discussion. Lastly, flouting maxims of manner is taken place if the speaker says ambiguous statement (Cutting, 2002; Levinson, 1983; Yule, 1996).

When the speakers flout the maxims, they use some strategies in order to convey the implicit meaning of their utterances. Based on the Cutting's theory (2002), "the strategy of flouting maxims are tautology, giving too much information, giving too less information, metaphor, hyperbole, irony, banter, sarcasm, being irrelevant and being obscure". In addition, these flouting maxims can be found in any situation such as real life or even in a movie or novel.

The researcher took movie as an object of the research by analyzing the utterances of the characters. As stated by (Putri et al., 2019) that movie is one of literature forms which contain story, play, history, culture, incidents, science, etc. that is recorded as video and shown in cinema, television, theaters, or other broadcast media which is as entertainment as the main purpose.

Furthermore, through a movie or film, people and the events around them can be recorded (Graham, 2005). By studying the flouting maxim in a movie, it can also reflects an analysis of flouting maxim in human life.

In this study, the object of the research is $U P$ movie. There are several reasons of choosing this movie to be analyzed. First, analyzing flouting maxims in a movie is interesting to be conducted since this movie represent the real example of flouting maxim in daily life. Second, this 
movie offer entertainment as well as good moral value. Lastly, through the conversation between the characters in this movie, some phenomena of flouting maxims is found.

Based on those explanation, there are two objectives of this study. Firstly, to analyze types of flouting maxim which are uttered by the characters in UP animated movie. Second, to explain the strategies of flouting maxim which are used by the characters in UP animated movie. In this case, the characters used the hidden meaning in their utterances. It is because the researcher would analyze the strategies so that the viewer could understand what implied meaning that the characters tried to convey in their utterances.

\section{MATERIALS AND METHOD}

This study employed pragmatic approach since pragmatics is the study of the role context plays in speaker (or utterance) meaning (Levinson, 1983). Additionally, pragmatic is the study under linguistics which focus on meaning in context, thus the meaning itself cannot be taken literally (Griffiths, 2006; Levinson, 1983). By using this approach, how people use language to deliver certain message in conversation can be analyzed. In this case, the characters in the movie used the hidden meaning in their utterances. Thus, the pragmatic approach is used to understand what implied meaning that the characters tried to convey in their utterances.

In this research, descriptive qualitative method also employed since it emphasized describing phenomena in its context. It is supported by Vanderstoep and Johnston (2009) who state that qualitative research is regarded as producing a narrative or textual description of the phenomena under study.

\section{RESULTS \& DISCUSSION}

\section{Types of Flouting Maxim Performed by the Characters in UP movie}

Identifying the types of flouting maxim is the first objective of this study. There are four types of flouting maxim which are found in this movie and this finding is in line with Cutting's theory (2002). The findings are presented in the table below followed by its discussion by giving one example in each types. 
Table 1. Types of flouting maxim in the character's utterances UP movie

\begin{tabular}{clcc}
\hline No & $\begin{array}{l}\text { Types of flouting } \\
\text { maxim }\end{array}$ & Frequency & Percentage \\
\hline $\mathbf{1}$ & $\begin{array}{l}\text { Flouting maxim of } \\
\text { quantity }\end{array}$ & 9 & $31.03 \%$ \\
$\mathbf{2}$ & $\begin{array}{l}\text { Flouting maxim of } \\
\text { quality }\end{array}$ & 11 & $37.93 \%$ \\
$\mathbf{3}$ & $\begin{array}{l}\text { Flouting maxim of } \\
\text { relation }\end{array}$ & 6 & $20.69 \%$ \\
$\mathbf{4}$ & $\begin{array}{l}\text { Flouting maxim of } \\
\text { manner }\end{array}$ & 3 & $10,35 \%$ \\
\hline & Total & 29 & $100 \%$ \\
\hline
\end{tabular}

Four types of flouting maxim is found in this study namely flouting maxim of quantity, flouting maxim of quality, flouting maxim of relation and flouting maxim of manner.

\section{Flouting maxim of quantity}

Flouting maxim of quantity occur when the speaker is giving too much information or giving too little information (Cutting, 2002). Here is an example of flouting maxim of quantity by giving too little information.

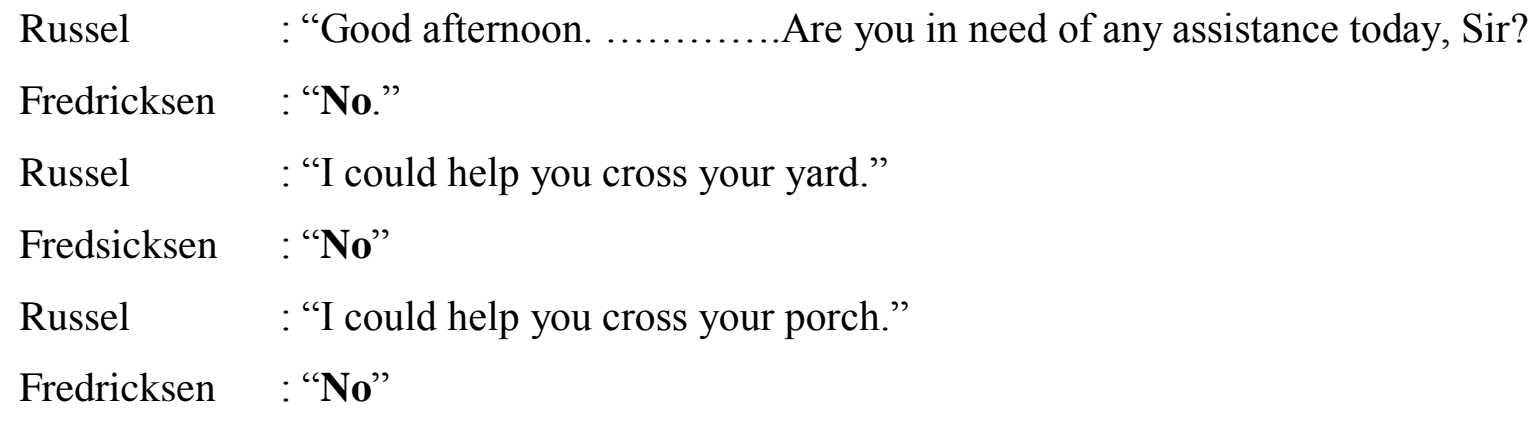

$(F M / Q N / U P / 00: 15: 40)$

This conversation happens in front of fredricksen's house. Russel says that he wants to offer help to Fredricksen. Russel is very interest to help. In responding to Russel's utterances, Fredricksen just says no. He answers by giving little information. Fredricksen responds with a very limited statement. Thus, this is considered as flouting maxim of quantity.

\section{Flouting maxim of quality}

Another type of flouting maxim is flouting maxim of quality. Flouting maxims of quality is taken place if the speaker says untruthful statement or something which is considered to be false (Cutting, 2002, p. 37). The excerpt below shows that the speaker flouts the maxim of quality. 
Dog : "I will not bite you. The small mailman smells like chocolate."

Charles : "I'm sorry about the dogs. Hope they weren't too rough on you. We weren't."

(FM/QLUUP/00:54:41)

In this conversations happen when Charles Muntz invites Fredricksen and Russel going to his airship. The dogs are not rude. And then Charles Muntz apologizes for the dogs. He hopes his dogs are not rude to Fredricksen and Russel. Charles Muntz fulfill flouts maxim of quality because he give untruthful statement or something that is considered to be false.

\section{Flouting maxim of relation}

The third type of flouting maxim is the flouting maxim of relation. It occurs when the speaker makes the conversation unmatched with the topic of discussion and giving irrelevant answer (Cutting, 2002, p. 39). The example of dialogue below shows the flouting maxim of relation.

Fredricksen : "We could walk it right over there. Like a parade balloon. Now, we're going to walk to the falls quickly and quietly... with no rap music or flash dancing. We have three days, at best, before the helium leaks out of those ballons. ...."

Russel : "I found sand"

$(F M / R / U P / 00: 33: 13)$

The conversation above happen in the forest near the paradise falls. Russell and Fredricksen walk towards the paradise falls while bringing the balloon house. Fredricksen gives some explanations about what should they do. But Russell's response is not relevance with the statement's fredricksen. Thus, maxim of relation is flouted by giving statement which is out of topic.

\section{Flouting maxim of manner}

Lastly, flouting maxims of manner is taken place if the speaker says ambiguous statement (Cutting, 2002). The excerpt below shows that the speaker flouts the maxim of manner.

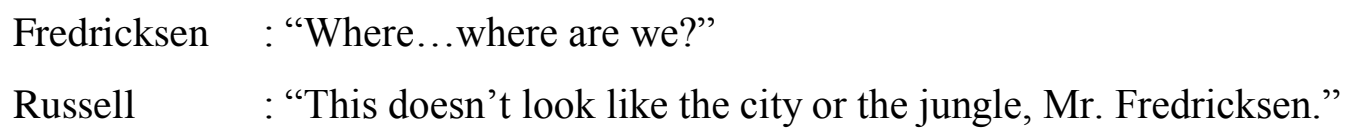

(FM/M/UP/00:30:49)

In the above conversation, Fredricksen asks Russell about they positions. Nevertheless, Russell flouts the maxims of manner in answering Fredricksen's question. Russel does not answer Fredricksen's question clearly. He says it's like city or jungle. Russell flouts the maxim of manner because he says ambiguous statement. 


\section{Strategies of Flouting Maxim Performed by the Characters in UP movie}

Describing the strategies of flouting maxim is the second objective in this study. The following strategies are found from the characters' utterance which are in line with Cutting's theory (2002) related to strategies of flouting maxims. The findings are presented in the table below followed by its discussion.

Table 2. Strategies of flouting maxim in the characters' utterances UP movie

\begin{tabular}{llll}
\hline No & \multicolumn{1}{c}{$\begin{array}{c}\text { Type of flouting } \\
\text { maxim }\end{array}$} & \multicolumn{1}{c}{ Strategies of flouting maxim } & Frequency \\
\hline 1. Quantity & Providing limited information & 4 \\
& Giving excessive information & 5 \\
2. Quality & Giving hyperbole statement & 1 \\
& & Giving irony statement & 3 \\
& Giving metaphor statement & 1 \\
& Giving banter statement & 2 \\
& & Giving sarcasm statement & 4 \\
3. & Relation & Changing the topic & 4 \\
& & Giving irrelevant statement & 2 \\
4. & Manner & Being not brief & 1 \\
& & Giving ambiguous information & 2 \\
\hline
\end{tabular}

As presented in table 2, the strategies which are found in this movie includes providing limited information, giving excessive information, hyperbole, metaphor, irony, banter, sarcasm, being irrelevant, changing the topic and being obscure.

\section{Giving excessive information}

Giving excessive information is one of the strategies to flout the maxim of quantity besides giving too little information (Cutting, 2002, p. 37). The excerpt below shows that the speaker giving excessive information to flout the maxim of quantity. 
Fredricksen : "Did you ever! Will you look at that?

Charles : "Oh, yes, the Arsinoitherium. Beast charged while I was brushing my

teeth. It used my shaving kit to bring him down. OH yeah. Well, surprise me. ONly wau to get it out of Ethiopia at the time..."

(FM/QN/TM/00:55:33)

The conversation above happens in "spirit adventure" (Muntz's ship). When Fredricksen saw the animal bones, he asked Muntz, you have seen it, and Muntz answered the question more than what exceeded what it needed. Fredricksen just ask "Did you ever!" but Muntz gives too much information. The statement "Oh, yes, the Arsinoitherium” it was enough.

\section{Providing limited information}

Besides providing excessive information, flouting maxim of quantity is also found by providing limited information. The excerpt below shows that the speaker providing limited information to flout the maxim of quantity.

Muntz : "Having guests is a delight. More often I get thieves come to steal what's rightfully mine."

Fredricksen : "No!"

(FM/QN/TL/UP/00:57:30)

The conversation happens when Fredricksen and Muntz want to eat in dining room's Muntz. Muntz says, "having guests is a delight. More often I get thieves come to steal what's rightfully mine" but Fredricksen responds just says "No". He flouts quantity maxim by giving limited information because he used answered short statement.

\section{Hyperbole}

One of strategies in flouting maxim of quality is hyperbole. Hyperbole means that the speakers exaggerate the fact (Cutting, 2002). The example below shows that speaker flouts the maxim of quality by exaggerating the fact.

Nurse : " That's typical. He's probably going to the bathroom for the $80^{\text {th }}$ time."

(FM/QL/H/UP/00:21:01)

This statement happened when Shady Oaks Nurse wanted to pick Fredricksen being taken to the Nursing Home. Fredricksen said "I'll meet you at the van in just a minute. I want to say one last goodbye to the old place." Then the nurse replied "Sure. Take all the time you need, sir." Then after Fredricksen close the door, the nurse said again "That's typical. He's probably going to 
the bathroom for the 80th time." From this statement, it can be seen that the speaker flout the maxim of quality since she used hyperbole language.

\section{Metaphor}

Another strategy which belongs to flouting maxim of quality is metaphor. Metaphor is used by the speaker in her/his utterance to show something different from actual meaning. Thus, the hearer is supposed to understand the implicit meaning from the statement that contain metaphor (Cutting, 2002). The example below shows that speaker flouts the maxim of quality by using metaphor.

Builder : : "Well, just to let you know, my boss will be happy to take this old place off your hands, and for double his last offer! What do you say to that?"

Fredricksen : "I believe I made my position to your boss quite clear."

Builder : :You poured prune juice in his gas tank."

Fredricksen : "yeah, that was good."

(FM/QL/M/UP/0:14:26)

The conversations happen in the front of Fredricksen's house when the builders said that his boss will be happy to take this old place off Fredricksen's hand for double last offer. But Fredricksen does not give it. And the builders replied with metaphor language. He said "you poured prune juice in his gas tank" it means fredricksen's house prevents the main view of the project because the position of the fredricksen's house is in front of the project. The builder's utterance is categorized as example of metaphor. Due to phrase indicate something different with literal meaning. It means the builders said that Fredricksen will make disappointed his boss and it will get back to his on it.

\section{Irony}

Irony is used if a speaker express a positive sentiment to express a negative sentiment. In short, it is aimed to mock or to tease people (Cutting, 2002). The example below shows that speaker flouts the maxim of quality by using irony.

"Here, let me talk to him. You are in the suit. Yes, you. Take a bath, hippie!"

(FM/QL/I/UP00:14:51)

The conversation happens Fredricksen is talking with builders about the boss's builder want to offer Fredricksen's house. And Fredricksen want to talk with the boss directly. He borrowed the loudspeaker and said "You are in the suit. Yes, you. Take a bath, hippie!" this statement fulfills 
the strategy flouting maxim of quality by the irony because the fredricksen's utterances used to mock language.

\section{Banter}

Unlike irony, banter is used if a speaker states a negative sentiment to express a positive one (Cutting, 2002). It is regarded as a friendly way since this strategy is used to praise others. The example below shows the use of banter.

Dog : "I will not bite you. The small mailman smells like chocolate."

$(F M / Q L / B / U P / 00: 54: 36)$

In this statement happens when Fredricksen and Russel were brought a group of dogs to meet Charles Muntz as their master as their prisoners. Then, after met Charles Muntz, he said that fredricksen and Russel are not our prisoners again but they are our guest. After that, Charles Muntz invites Fredricksen and Russel to enter his airship. And dog said "I will not bite you, the small mailman smells like chocolate".

This strategy is regarded as flouting maxim of quality since the utterance implies a positive sentiment. When the dog says "I will not bite you the small mailman smells like chocolate", it actually means that they are friendly to their guests.

\section{Sarcasm}

Sarcasm is happened if a speaker says something that is opposite of what is proper and usually in a mocking tone. Sarcasm shows less friendly attitude and it is frequently used to criticize (Cutting, 2002). Here an example related to the phenomenon.

"You think he'd take better care of his house (seeing a messy house)"

$(F M / Q L / S / U P / 00: 21: 05)$

This statement happens when nursing pick up Fredricksen in Fredricksen's house. Fredricksen needs time for saying good bye to his house and he closed the door directly. After that, the nurses going to the bus and he saw the home page is very messy. He said to his friends that "You think he'd take better care of his house" this statement shows sarcasm because it is critic for Fredricksen cannot take better care of his house. 


\section{Changing the topic}

Changing a topic and giving irrelevant answer are the two strategies of flouting maxim of relation. The first is by changing the topic and the second is by giving irrelevant answer. The excerpt below is an example of changing the topic.

$\begin{array}{ll}\text { Russel } & \text { : "I liked his other voice." } \\ \text { Charles Muntz } & \text { : "Dinner is served. Right this way." }\end{array}$

$(F M / R / C T / U P / 00: 56: 21)$

From the conversation, Russel looks Charles muntz fixed the dog voice, and he said "I liked his other voice" but Charles Muntz answer unmatched with the Russel's statement. He said that "the dinner is served" and he shows the road to the dining room. It can be seen that Muntz actually changes the topic which is not related to the previous conversation. Thus, it is categorized as flouting maxim of relation.

\section{Giving irrelevant answer}

In the discussion, being relevant does not usually expressed by giving response. Nevertheless, there are usually implicit meanings through irrelevant response. This phenomena flouts the maxim of relation (Cutting, 2002). The following excerpt is an example of giving irrelevant answer.

Russel : "I know that cloud. It's a cumulonimbus. Did you know that ... the cumulonimbus forms ... when warm air rises over cool air?"

Fredricksen : "Stayed up all night blowing up balloons ... for what?"

$(F M / R / I R / U P / 00: 26: 17)$

This conversation happens when Russel looks in the window. He saw the cloud. It is cumulonimbus. And he asks to Fredricksen did you know that what cumulonimbus is. But Fredricksen says, "stayed up all night blowing up balloons ... for what?" the Fredricksen utterance is not relevant with the Russel's questions. From his irrelevant answer, it can be seen that Fredricksen flouts maxim of relation.

\section{Being obscure (not brief)}

Being obscure and being ambiguous are two strategies of flouting maxim of manner. By being obscure, the speaker should be perspicuous what is said and ambiguity in his utterance (Cutting, 2002). Below is an example of flouting maxim of manner by being obscure. 


\begin{abstract}
Russel : : "Good afternoon ..."
Fredricksen : "But skip to the end!"

Russel : "See these? These are my Wilderness Explorer badges. You may notice one is missing. It's my assisting the Elderly badge. If I get it, I will become a Senior Wilderness Explorer. "The wilderness must be explored!" Caw, caw! Raar! It's going to be great! There's a big ceremony, and all the dads come, and they pin on our badges.
\end{abstract}

$(F M / M / O / U P / 00: 16: 21)$

The conversations happen when Russel comes to Fredricksen's house, and Fredricksen asks to him directly. And Russel does not simply say "he wants to help Fredricksen anything to get a assisting the elderly badge". But Russel answer he does not mentioning the point what he want. By the Russel's utterances, he fulfill flouts maxim of manner by being obscure. He should be perspicuous what is said.

\title{
CONCLUSION
}

Based on the data findings, it can be concluded that all maxims are flouted. There are 29 data that represent the most dominant of flouting maxim in the utterances of the characters in $U P$ movie.

In reference to the data analysis, there are four type flouting maxim in this study. There are flouting maxim of quality, quantity, relation, and manner. The occurrences each types flouting maxim are difference in the movie. The highest occurrence type is flouting maxim of quality with $37.93 \%$ because the characters deliberately say something that is believe to be false.

Regarding strategies used by the characters, ten strategies of flouting maxim are found in this movie. These are giving excessive information, providing limited information, hyperbole, metaphor, irony, banter, sarcasm, being irrelevant and being not brief. The occurrence of the strategy used to flout maxim is a giving excessive information with 5 out of 29 times. It makes the strategy of flouting maxim by giving excessive information is the first rank in this research.

This research reflects significant impact in daily life. By understanding flouting maxim, both speaker and listener can avoid misunderstanding since the daily conversations sometimes does not work effectively. Sometimes, the speaker does not aware that they break the rules of communication when they are talking about some things with the listener. Communication will be successful when the speaker and the listener understand more about flouting maxim. It means the speaker knows what is the different between literal meaning and implied meaning and the listener is expected to understand the implicit meaning from the speaker's actual utterance. 


\section{ACKNOWLEDGEMENT}

I gratefully thank Lembaga penelitian \& Pengabdian Masyarakat (LPPM) STBA Techocrat Tangerang for giving the opportunity and financial support to me to conduct the research.

\section{REFERENCES}

Cutting, J. (2002). Pragmatics and discourse: A resource book for students. Routledge.

Graham, G. (2005). Philosophy of the Arts. In Philosophy of the Arts. https://doi.org/10.4324/9780203244937

Grice, H. P. (1989). Studies in the way of words. In New York: Academic Press. Harvard University Press. http://www.sfu.ca/ jeffpell/Cogs300/GriceLogicConvers75.pdf

Griffiths, P. (2006). An introduction to English semantics and pragmatics. Edinburgh University Press Ltd.

Grundy, P. (2000). Doing pragmatics. Routledge.

Levinson, S. C. (1983). Pragmatics. Cambridge University Press, 1-9.

Mey, J. L. (1993). Pragmatics: An introduction. Blackwell Publishing. https://books.google.co.id/books/about/Pragmatics.html?id=TT_TF4sM6lcC\&redir_esc=y\%0Ah ttp://dlx.book.org/genesis/615000/65cf48ea94750adac474d87f5994986b/_as/\%5BJacob_Mey\%5 D_Pragmatics_An_Introduction_(2nd_ed)(b-ok.org).pdf

Putri, A., Mujiyanto, J., \& Sofwan, A. (2019). Journal of English Language Teaching THE IMPLEMENTATION OF TRANSPOSITION TRANSLATION PROCEDURES IN ENGLISHINDONESIAN TRANSLATION OF EPIC MOVIE SUBTITLE. Journal of English Language Teaching, 6(1), 1-7. http://journal.unnes.ac.id/sju/index.php/elt\%0ATHE

Thomas, J. (1995). Meaning in interaction: An introduction to pragmatics. Routledge.

Ulfah, R. A. A. N., \& Afrilia, R. (2018). an Analysis of Flouting Maxim in "the B.F.G" Movie. PROJECT (Professional Journal of English Education), 1(5), 687. https://doi.org/10.22460/project.v1i5.p687-695

Vanderstoep, S. W., \& Deirdre D., J. (2009). Reseach method for everyday life. Jossey-Bass.

Wahyuni, M., Arifin, M. B., \& Lubis, I. S. (2019). An analysis of flouting maxims done by main characters in $\mathrm{La} \mathrm{La}$ land movie. Jurnal Ilmu Budaya, 3(3), 384-392. https://doi.org/http://dx.doi.org/10.5281/ilmubudaya.v3i3.2212

Yule, G. (1996). Pragmatic. Oxford University Press. 